\title{
The forgotten tigers: the arboreal tiger beetles of Sri Lanka
}

\author{
Chandima Deepani Dangalle* \\ Department of Zoology and Environment Sciences, Faculty of Science, University of Colombo, Colombo 03.
}

Summary: Thirty-one species of arboreal tiger beetles are known to occur in Sri Lanka of which twenty-five species are stated to be endemic. However, the group has not been studied for more than a century and the last organised records are provided by Fowler (1912) in his studies of the 'Fauna of British India including Ceylon and Burma (Coleoptera General Introduction and Cicindelidae and Paussidae)'. Due to high endemicity rates, biodiversity value and current disturbances and destruction to natural forests of the country, which are the main habitat types of the arboreal tiger beetles, it is important that this insect group be thoroughly studied. Therefore, a study was initiated on the 'Diversity, distribution and habitat types of arboreal tiger beetles (Coleoptera, Cicindelinae) of Sri Lanka', funded by the National Science Foundation of Sri Lanka. This review compiles and records previous information on the arboreal tiger beetles of Sri Lanka, which will provide a foundation for future studies and reveal gaps in the knowledge of this insect group. The review discusses: 1) taxonomy of the arboreal tiger beetles, highlighting the genera found in Sri Lanka and their affinities to arboreal tiger beetle genera elsewhere in the world; 2) previous locations and distribution of species throughout the island and districts and provinces from which species are not recorded, habitat and micro-habitat types; 3 ) morphological characters of genera and species and unique characters used for the separation of species, life-cycle strategies; and 4) methods employed to collect arboreal tiger beetle species and threats to the survival of this insect group.

Keywords: Arboreal tiger beetles, historical records, Sri Lanka.

\section{INTRODUCTION}

Tiger beetles are predatory beetles of the order Coleoptera, family Carabidae and sub-family Cicindelinae (Roza $\&$ Mermudes, 2017). The sub-family consists of
2,822 species of 120 genera that are included into five tribes - Amblycheilini, Manticorini, Megacephalini, Collyridini and Cicindelini (Ball et al., 2011; Roza \& Mermudes, 2017). Two tribes are found in Sri Lanka; Cicindelini, consisting of ground dwelling tiger beetles, and Collyridini consisting of arboreal tiger beetles. Forty species of ground dwelling tiger beetles of which fourteen species are potentially endemic and thirty-one species of arboreal tiger beetles of which twenty-five are potentially endemic were found on the island (Tennent, 1860; Horn, 1904; Fowler, 1912; Naviaux, 1984; 1986; 1995; Acciavatti \& Pearson, 1989). Therefore, Sri Lanka is ranked number one amongst the top ten countries with the highest tiger beetle species coverage, and number four amongst the top ten countries with highest percentage of endemic tiger beetle species (Santos, 2011).

The ground dwelling tiger beetles of Sri Lanka have been extensively studied, and species lists (Tennent, 1860; Horn, 1904; Fowler, 1912; Naviaux, 1984; Acciavatti \& Pearson, 1989), locations and distributions (Horn, 1904; Fowler, 1912; Naviaux, 1984; Acciavatti \& Pearson, 1989), endemic species (Dangalle et al., 2011a; 2011b), habitat types (Dangalle et al., 2012a; 2014a; Dangalle, 2013), habitat specificity (Dangalle et al., 2012b), phylogenetic relationships based on mitochondrial DNA (Dangalle et al., 2014b), body size and habitat relationships (Dangalle et al., 2013a; Edirisinghe et al., 2014), co-occurrence of species (Dangalle \& Pallewatta, 2015) and bioindicator potential (Dangalle, 2012; Thotagamuwa et al., 2016) are well known. However, the arboreal tiger beetles of Sri Lanka have been scarcely studied and detailed information on the species is only

*cddangalle@gmail.com; (iD https://orcid.org/0000-0001-9483-3895

This article is published under the Creative Commons CC-BY-ND License (http://creativecommons.org/licenses/by-nd/4.0/) This license permits use, distribution and reproduction, commercial and non-commercial, provided that the original work is properly cited and is not changed in anyway. 
given by Fowler (1912). Tennent (1860), Horn (1904) and Naviaux (2002) provide the species names that occur in Sri Lanka, while one species is discussed in detail by Naviaux (1995). Considering the high endemicity rate of $80 \%$ of arboreal tiger beetles, increased habitat degradation and forest destruction due to developmental activities of the country, it is imperative that the arboreal tiger beetles of Sri Lanka be studied and documented.

\section{Past records on the arboreal tiger beetle species of Sri Lanka}

Arboreal tiger beetles are commonly found in the tropics and subtropics of Asian countries inhabiting plant leaves and branches in forests (Toki et al., 2017). About 470 species are described in the world and are included in the tribe Collyridini, which is further divided into three subtribes - Ctenostomina, Collyridina and Tricondylina (Toki et al., 2017). Subtribe Ctenostomina consists of the genera Pogonostoma Klug and Ctenostoma Klug, which are considered as ancient relics of former Gondwanaland (Cassola, 2000a). Pogonostoma is an endemic genus found in Madagascar and is represented by 81 species inhabiting the evergreen eastern rain forests (Andriamampianina et al., 2000). Genus Ctenostoma, the closest relative to genus Pogonostoma is a neotropical genus and is found in the dark mid-strata of tropical vegetation from southern Mexico to the northern border of Argentina (Cassola, 2000a). Neither of these genera are found in Sri Lanka, and the island is only inhabited by species of the subtribes Collyridina and Tricondylina.

Collyridina of Sri Lanka consists of two genera, Collyris Fabricius and Neocollyris Horn, while Tricondylina also consists of two genera Tricondyla Latreille and Derocrania Chaudoir (Horn, 1904; Fowler, 1912; Erwin, 1984). However, Naviaux (2002) has described a fifth genus, Protocollyris Mandl from the country consisting of only a single species. The highest number of species are recorded from the genera Derocrania and Neocollyris; Derocrania consists of 12 species of which all are endemic to the island, while Neocollyris also consists of 12 species of which 9 species are endemic. Genus Tricondyla consists of 5 species of which 3 are endemic. Genus Collyris consists of a single species that is not endemic to the country (Table 1).

All five genera are also found in India (Saha \& Halder, 1986; Saha et al., 1995; Bhargav et al., 2009; Cassola, 2011), while three genera - Collyris, Neocollyris and Tricondyla are found in Thailand (Naviaux, 1991). Species of Collyris and Neocollyris have been recorded from Vietnam (Erwin \& House, 1978; Toki et al., 2017), and Neocollyris and Tricondyla from the Philippine Islands (Trautner \& Schawaller, 1996; Cassola, 2000b) and Hong Kong (Aston, 2016). Tricondyla are also known from Brunei (Damken et al., 2017).

These records are in accordance with Erwin's (1984) idea that the ground beetle fauna of Sri Lanka has its origins in the North, mainly the Oriental region. However, many of the arboreal tiger beetle species are endemic to Sri Lanka and only a few species are common with other countries - Tricondyla femorata Walker, T. tumidula Walker, Neocollyris crassicornis Dejean, $N$. bonellii Guérin-Méneville, $N$. andrewesi Horn and Collyris dohrnii Chaudoir.

Arboreal tiger beetles are known from Sri Lanka since 1860 when Emerson Tennent first recorded two species of the genus Tricondyla; T. femorata, T. tumidula and two species of the genus Derocrania; D. scitiscabra Walker, D. concinna Chaudoir. In 1904, Walther Horn provided a synopsis of 22 arboreal tiger beetles of all four genera - Collyris, Neocollyris, Tricondyla, Derocrania, but indicated his doubts of three species, C. bonellii, $N$. andrewesi and T. tumidula as belonging to the arboreal tiger beetle fauna of Sri Lanka. In 1912, Fowler in his studies of the Fauna of British India provided a more descriptive categorisation of the arboreal tiger beetles of Sri Lanka by grouping arboreal tiger beetles into the subfamily Collyrinae and dividing it into two groups. The first group is characterised by species with wings, seven teeth on labrum and females with two small sharp projections on the posterior margin of the last ventral segment of abdomen. The second group is characterised by species without wings, six labral teeth and females with no projections on the abdomen. The species of genera Collyris and Neocollyris are included in the first group, while the species of the genera Tricondyla and Derocrania are included in the second group. Fowler (1912) listed 20 arboreal tiger beetle species from Sri Lanka from all four genera. In 1995, Roger Naviaux, a French entomologist known for his work on beetles described a new endemic arboreal tiger beetle species, Neocollyris vedda, from Ratnapura. Later in 2002, Naviaux listed 27 species from all five genera.

Specimens of many of these species can be observed at the National Museum of Colombo and Horticultural Crop Research and Development Institute, Gannoruwa (Table 1).

\section{Distribution and habitat types of arboreal tiger beetles of Sri Lanka}

Distributional data on arboreal tiger beetles of Sri Lanka are only provided by Horn (1904), Fowler (1912), and collections of the National Museum of Colombo and Horticultural Crop Research and Development Institute, 
Table 1: Arboreal tiger beetle species of Sri Lanka according to previous literature

\begin{tabular}{|c|c|c|c|c|c|c|c|c|}
\hline & Species & $\begin{array}{c}\text { Tennent, } \\
1860\end{array}$ & $\begin{array}{c}\text { Horn, } \\
1904\end{array}$ & $\begin{array}{c}\text { Fowler, } \\
1912\end{array}$ & $\begin{array}{c}\text { Naviaux, } \\
1995\end{array}$ & $\begin{array}{c}\text { Naviaux, } \\
2002\end{array}$ & $\begin{array}{l}\text { National } \\
\text { Museum, } \\
\text { Colombo }\end{array}$ & $\begin{array}{c}\text { HORDI, } \\
\text { Gannoruwa }\end{array}$ \\
\hline 1. & Tricondyla femorata & $\sqrt{ }$ & - & - & - & $\sqrt{ }$ & - & - \\
\hline 2. & Tricondyla tumidula & $\sqrt{ }$ & $\sqrt{ }$ & - & - & - & & \\
\hline 3. & *Tricondyla coriacea & - & $\sqrt{ }$ & $\sqrt{ }$ & - & $\sqrt{ }$ & $\sqrt{ }$ & $\sqrt{ }$ \\
\hline 4. & *Tricondyla nigripalpis & - & $\sqrt{ }$ & $\sqrt{ }$ & - & $\sqrt{ }$ & $\sqrt{ }$ & $\sqrt{ }$ \\
\hline 5. & *Tricondyla granulifera & - & $\sqrt{ }$ & $\sqrt{ }$ & - & $\sqrt{ }$ & $\sqrt{ }$ & $\sqrt{ }$ \\
\hline 6. & *Derocrania scitiscabra & $\sqrt{ }$ & $\sqrt{ }$ & $\sqrt{ }$ & - & $\sqrt{ }$ & $\sqrt{ }$ & - \\
\hline 7. & *Derocrania concinna & $\sqrt{ }$ & $\sqrt{ }$ & $\sqrt{ }$ & - & $\sqrt{ }$ & $\sqrt{ }$ & $\sqrt{ }$ \\
\hline 8. & *Derocrania nietneri & - & $\sqrt{ }$ & $\sqrt{ }$ & - & $\sqrt{ }$ & $\sqrt{ }$ & $\sqrt{ }$ \\
\hline 9. & *Derocrania fusiformis & - & $\sqrt{ }$ & $\sqrt{ }$ & - & $\sqrt{ }$ & $\sqrt{ }$ & - \\
\hline 10. & *Derocrania gibbiceps & - & $\sqrt{ }$ & $\sqrt{ }$ & - & $\sqrt{ }$ & $\sqrt{ }$ & $\sqrt{ }$ \\
\hline 11. & *Derocrania flavicornis & - & $\sqrt{ }$ & $\sqrt{ }$ & - & $\sqrt{ }$ & - & - \\
\hline 12. & *Derocrania nematodes & - & $\sqrt{ }$ & $\sqrt{ }$ & - & $\sqrt{ }$ & $\sqrt{ }$ & $\sqrt{ }$ \\
\hline 13. & *Derocrania schaumi & - & $\sqrt{ }$ & $\sqrt{ }$ & - & $\sqrt{ }$ & $\sqrt{ }$ & $\sqrt{ }$ \\
\hline 14. & *Derocrania halyi & - & $\sqrt{ }$ & $\sqrt{ }$ & - & $\sqrt{ }$ & $\sqrt{ }$ & - \\
\hline 15. & *Derocrania agnes & - & - & $\sqrt{ }$ & - & $\sqrt{ }$ & $\sqrt{ }$ & - \\
\hline 16. & *Derocrania intricatorugulosa & - & - & - & - & $\sqrt{ }$ & - & - \\
\hline 17. & *Derocrania jaechi & - & - & - & - & $\sqrt{ }$ & - & - \\
\hline 18. & *Protocollyris planifrons & - & - & - & - & $\sqrt{ }$ & - & - \\
\hline 19. & Collyris dohrnii & - & $\sqrt{ }$ & $\sqrt{ }$ & - & $\sqrt{ }$ & $\sqrt{ }$ & $\sqrt{ }$ \\
\hline 20. & Neocollyris crassicornis & - & $\sqrt{ }$ & $\sqrt{ }$ & - & $\sqrt{ }$ & $\sqrt{ }$ & $\sqrt{ }$ \\
\hline 21. & *Neocollyris saundersii & - & $\sqrt{ }$ & $\sqrt{ }$ & - & $\sqrt{ }$ & $\sqrt{ }$ & $\sqrt{ }$ \\
\hline 22. & *Neocollyris punctatella & - & $\sqrt{ }$ & $\sqrt{ }$ & - & $\sqrt{ }$ & $\sqrt{ }$ & - \\
\hline 23. & *Neocollyris plicaticollis & - & $\sqrt{ }$ & $\sqrt{ }$ & - & $\sqrt{ }$ & $\sqrt{ }$ & - \\
\hline 24. & *Neocollyris ceylonica & - & $\sqrt{ }$ & $\sqrt{ }$ & - & $\sqrt{ }$ & $\sqrt{ }$ & - \\
\hline 25. & Neocollyris bonellii & - & $\sqrt{ }$ & - & - & - & - & - \\
\hline 26. & *Neocollyris planifrons & - & $\sqrt{ }$ & $\sqrt{ }$ & - & - & $\sqrt{ }$ & - \\
\hline 27. & Neocollyris andrewesi & - & $\sqrt{ }$ & - & - & - & $\sqrt{ }$ & - \\
\hline 28. & *Neocollyris vedda & - & - & - & $\sqrt{ }$ & $\sqrt{ }$ & - & - \\
\hline 29. & *Neocollyris aenea & - & - & - & - & $\sqrt{ }$ & - & - \\
\hline 30. & *Neocollyris sedlaceki & - & - & - & - & $\sqrt{ }$ & - & - \\
\hline 31. & *Neocollyris planifrontoides & - & - & - & - & $\sqrt{ }$ & - & - \\
\hline
\end{tabular}

* Endemic species; HORDI - Horticultural Crop Research and Development Institute

Gannoruwa. According to these data, arboreal tiger beetles are found in all nine provinces of the three climatic zones - wet, dry and intermediate. However, they have only been recorded from 16 of the 25 districts of the country and have not been recorded from Jaffna and Mannar Districts of the Northern Province; Polonnaruwa District of the North-Central Province; Batticaloa District of the Eastern Province; Kegalle District of the Sabaragamuwa Province; Gampaha, Kalutara Districts of the Western Province and Galle, Matara Districts of the Southern Province (Table 2, Figure 1).
Collyris dohrnii, the single species of the genus Collyris of Sri Lanka, is recorded from locations of five provinces Northern, North-Central, Eastern, Uva and Western (Table 2) of the country but does not reveal their habitats. However, Horn (1931) in his surveys in Hong Kong recorded species of Collyris found on leaves and twigs of bushes, seldom settling on flowers, which may be the habitat of C. dohrnii of Sri Lanka.

The twelve species of Neocollyris of the country inhabit many locations of the Northern, Eastern, Central, 


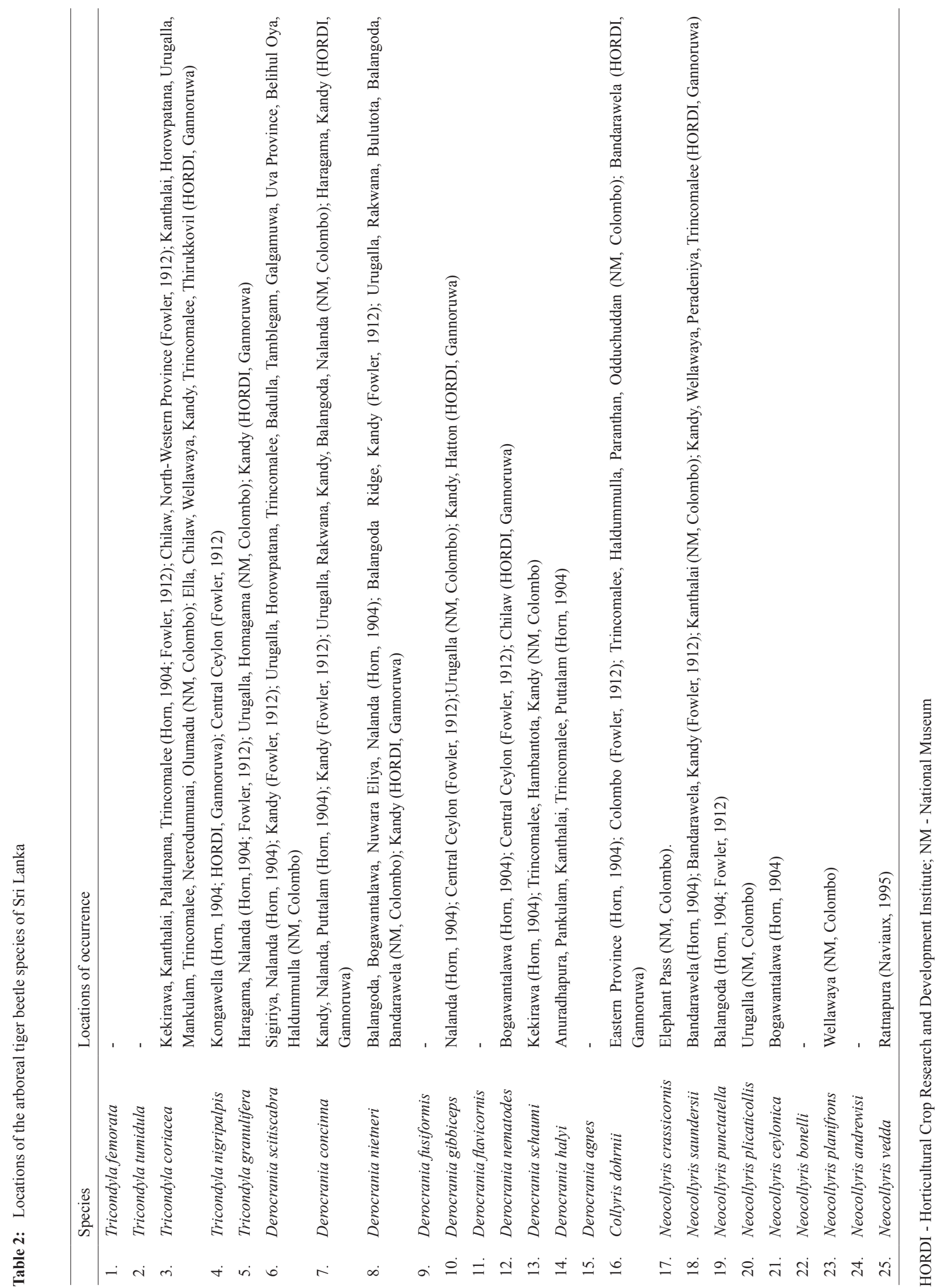



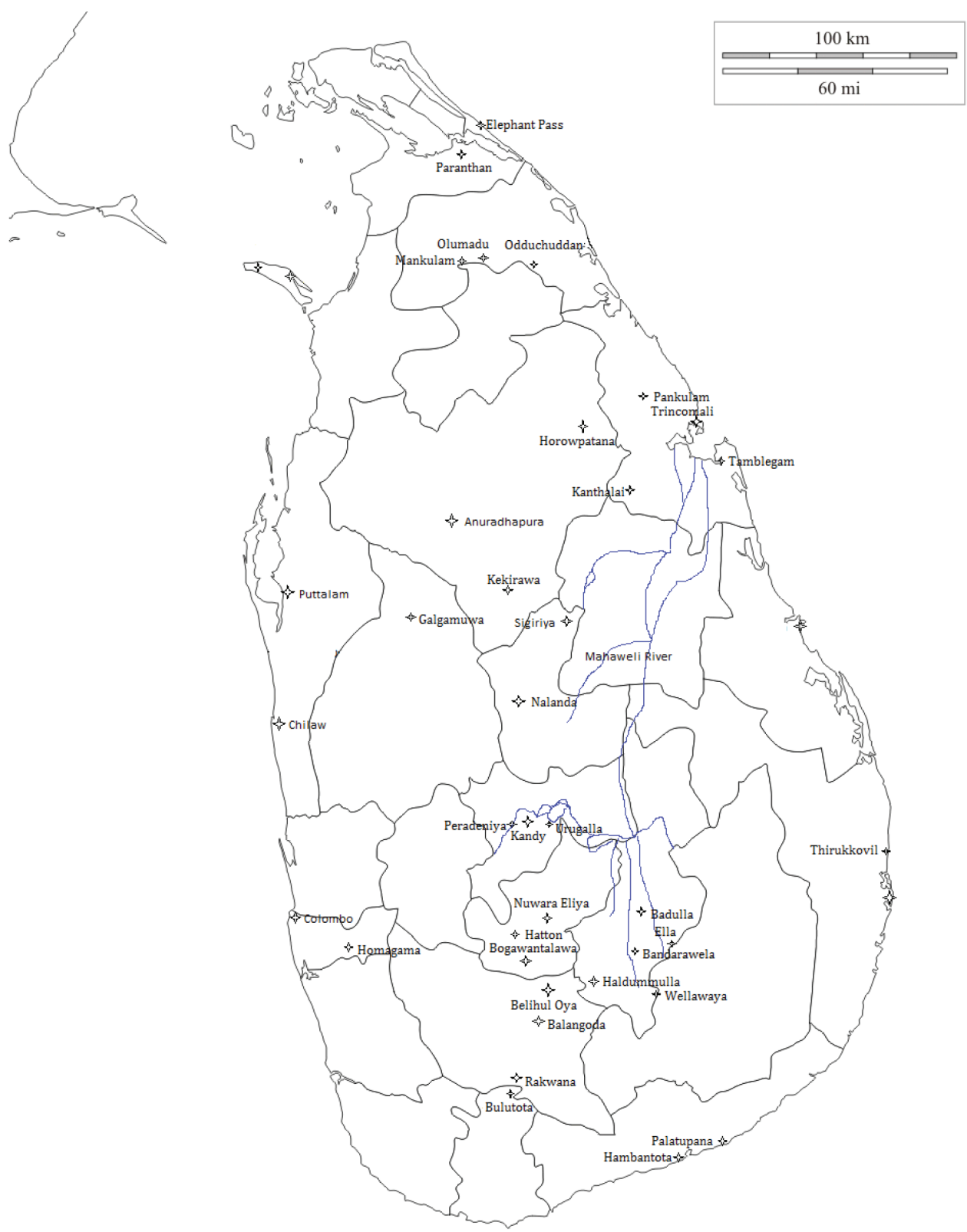

Figure 1: Locations of occurrence of the arboreal tiger beetles of Sri Lanka (according to previous literature)

Uva and Sabaragamuwa Provinces (Table 2), but habitats are only recorded for $N$. crassicornis. According to Fowler (1912), this species has been reported from jungles with less dense vegetation. They have been found running on leaves of shrubs, and flying rapidly from shrub to shrub. However, different species of Neocollyris have been recorded from green vegetation of forests (Saha \& Halder, 1986), mixed dipterocarp forests, secondary forest edges, understory vegetation (Damken et al., 2017) and wildlife sanctuaries (Bhargav et al., 2009) of India; branches of coffee plants in Vietnam (Toki et al., 2017); and grasses and leaves of small Ficus hispida Linnaeus trees of Hong Kong (Aston, 2016).

Genus Derocrania consisting of twelve species is found in eight provinces of Sri Lanka, excluding the Northern Province. Fowler (1912) described the habitat of D. scitiscabra as tree trunks of forests.

The five species of genus Tricondyla of Sri Lanka display a wide distribution and are recorded from eight Provinces of the island with the exception of the Southern 
Province. Although the habitats have not been recorded for the species of Sri Lanka, according to Horn (1931), they occur on tree trunks up to a height of several feet. In Hong Kong $T$. pulchripes White has been recorded on tree trunks (Horn, 1931; Aston, 2016) and is known to frequent Lichi trees (Aston, 2016). Tricondyla aptera Olivier have been collected from the leaves and ground cover in jungle forests of Manila, the Philippine Islands (Tanner, 1951).

\section{Morphology of arboreal tiger beetles}

Arboreal tiger beetles have an elongate, slender body with a large head and prominent eyes (Figure 2) (Fowler, 1912). They differ from ground-dwelling tiger beetles by having an elongate slender body and very narrow, strongly furrowed episterna of the metasternum (Fowler, 1912; Saha et al., 1995). The tribe consists of five genera of which Collyris and Neocollyris have wings that are capable of flight, labrum with seven teeth and two small projections on the posterior edge of the last abdominal segment of female. Tricondyla and Derocrania have

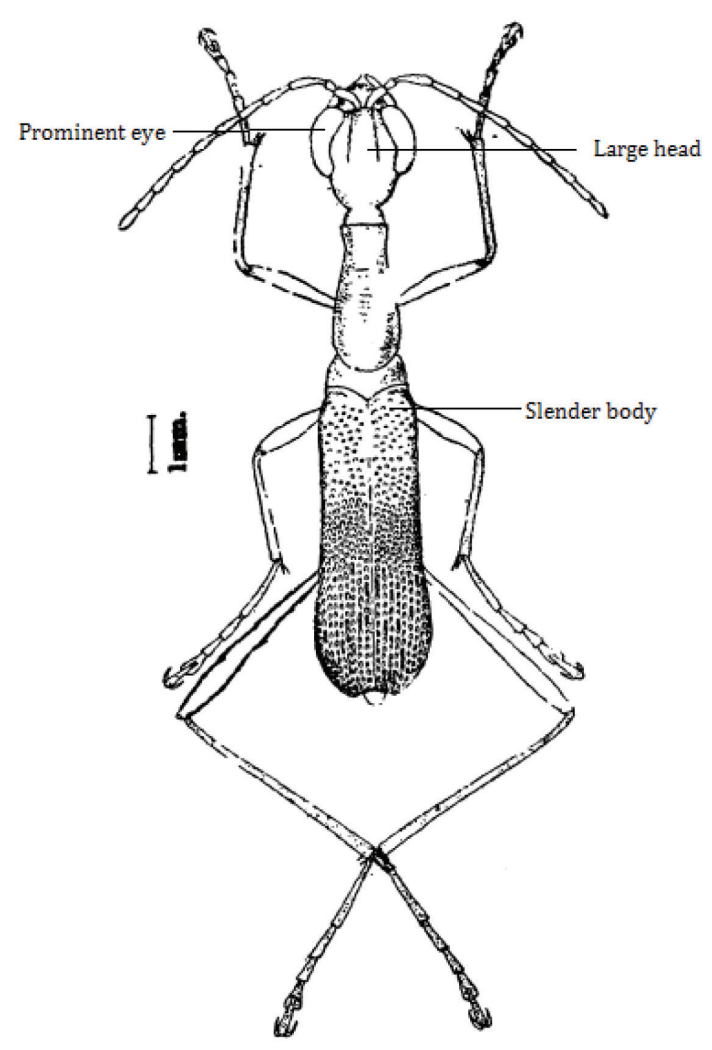

Figure 2: Dorsal view of the arboreal tiger beetle Neocollyris shyamrupi (adapted from Saha \& Halder, 1986) fused or rudimentary wings incapable of flight, six labral teeth and females lacking projections on the last abdominal segment (Fowler, 1912; Saha et al., 1995).

Species of the genus Collyris are larger $(\sim 27 \mathrm{~mm})$ than species of the genus Neocollyris $(9-21 \mathrm{~mm})$ and have a head that is widely, deeply and roundly excavated between the eyes. Vertex behind the eyes is very short (Figure 3) (Fowler, 1912; Saha et al., 1995; Wu \& Shook, 2007). Four species are known to occur in India, Thailand and Nepal - Collyris longicollis Fabricius, Collyris dohrnii, Collyris brevipennis Horn and Collyris mniszechi Chaudoir. All the species are bright blue, purple or black and C. longicollis, C. dohrnii and C. brevipennis have elytra that are not plicate at the center. The species C. longicollis has a pronotum that is strongly constricted at the base, while $C$. dohrnii and $C$. brevipennis lack this constriction. However, $C$. dohrnii has long elytra that are less regularly punctured while $C$. brevipennis has short elytra that are more regularly punctured. Collyris mniszechi has elytra that are plicate at the center (Fowler, 1912). Only C. dohrnii is found in Sri Lanka.

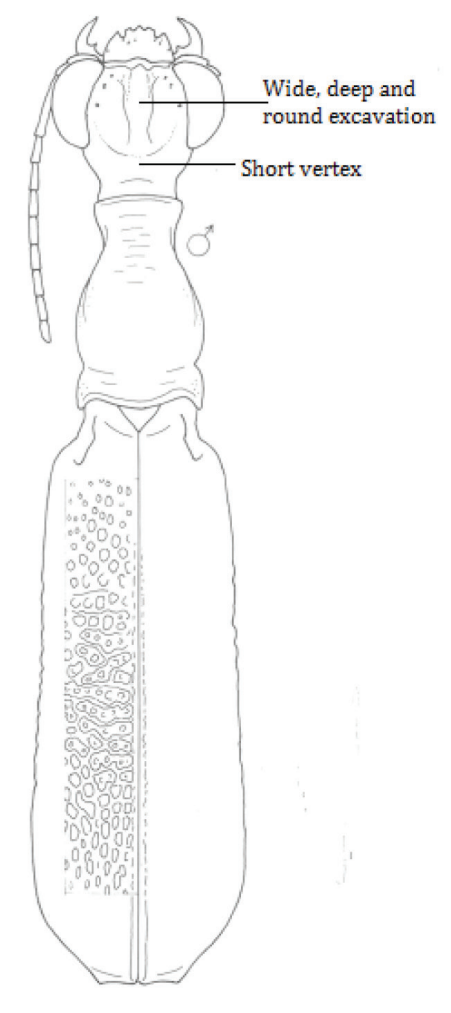

Figure 3: Habitus of Collyris mniszechi (adapted from Naviaux, 1991) 
Genus Neocollyris consists of species that are smaller in size and have a narrow space between the eyes that is strongly impressed. Vertex behind the eyes is long and most species are blue, green or violaceous in colour (Figure 4) (Fowler, 1912; Saha et al., 1995). The genus contains about 100 species of which twelve are found in Sri Lanka. Neocollyris planifrons Horn, N. punctatella Chaudoir, N. ceylonica Chaudoir and N. schaumi Horn are species that are small in size with less prominent eyes. Neocollyris planifrons differs from the other three species by possessing a long labrum, whereas the labrum is short in the others (Fowler, 1912). Neocollyris bonellii that occurs in India and other Asian countries in addition to Sri Lanka is intermediate in size with more prominent eyes. The species is metallic blue or green with a strongly dilated pronotum with a basal constriction. Neocollyris crassicornis Dejean, $N$. saundersii Chaudoir, $N$. andrewesi Horn and N. plicaticollis Chaudoir are species that are larger in size. Neocollyris crassicornis and $N$. saundersii have broad short heads, green, blue, violaceous, blackish colours and antennae that are strongly thickened towards the apex. In N. crassicornis

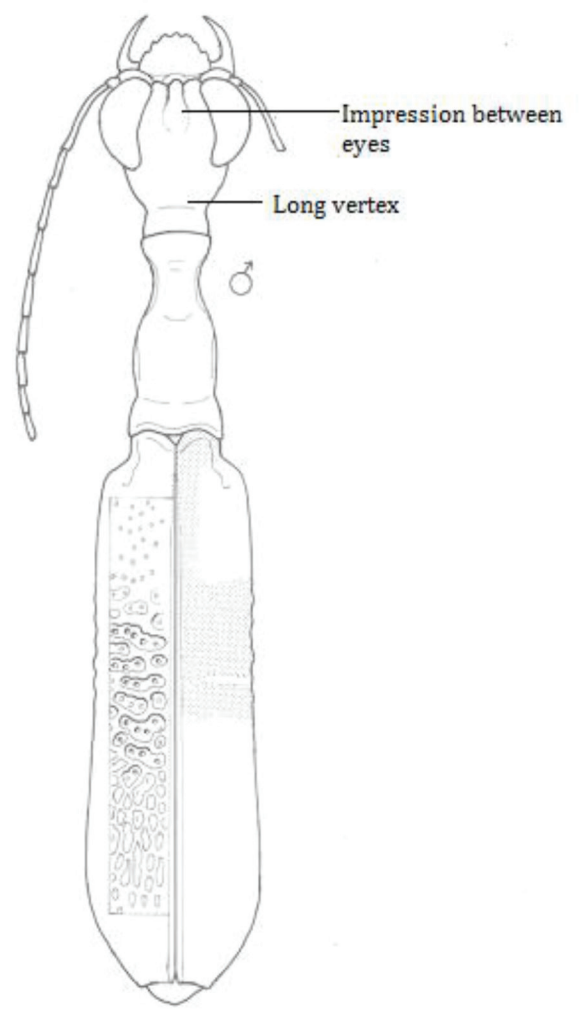

Figure 4: Habitus of Neocollyris tricolor (adapted from Naviaux, 1991) the pronotum is short and strongly dilated before base, while $N$. saundersii has a longer pronotum not strongly dilated before base (Fowler, 1912). Both $N$. andrewesi and $N$. plicaticollis have antennae that are not thickened towards the apex. The two species can be distinguished from each other by the frontal excavation on the head, which is broader in $N$. andrewesi when compared with N. plicaticollis (Fowler, 1912).

Species of the genus Tricondyla have large heads that are strongly concave between the eyes (Fowler, 1912; Wu $\&$ Shook, 2007). The eyes are large and very prominent and antennae are long and filiform. Labrum is large with six teeth; the central four broad and blunt and the lateral two sharper. Mentum is very short at base with central tooth absent or rudimentary, while the pronotum is more or less parallel sided and broad with constrictions in front and behind (Fowler, 1912; Saha et al., 1995). Elytra are fused at the suture, base narrow and apical one-third expanded in both lateral and dorsal view (Wu \& Shook, 2007). The legs are very long (Figure 5) (Fowler, 1912; Saha et al., 1995).

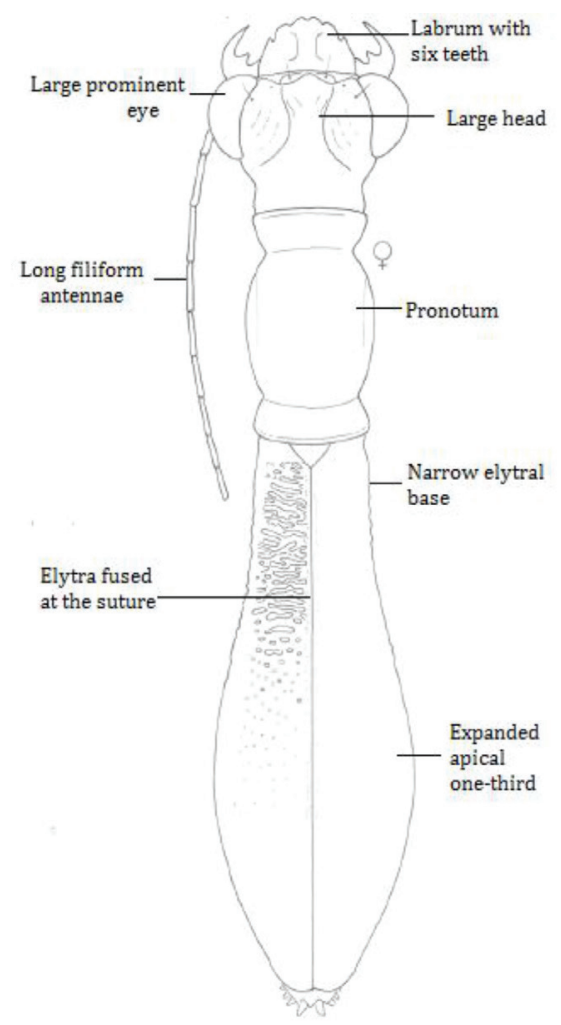

Figure 5: Habitus of Tricondyla annulicornis SchmidtGoebel (adapted from Naviaux, 1991) 
Nine species have been recorded from India and Sri Lanka (Fowler, 1912; Saha et al., 1995) of which three have been recorded from Sri Lanka - Tricondyla coriacea Chevrolat, T. nigripalpis Horn and $T$. granulifera Motschulsky (Fowler, 1912). According to Tennent (1860) and Horn (1904), two other species - T. femorata and T. tumidula that are not known in the works of Fowler (1912) and Saha et al.(1995) are also known to have occurred in the country.

When considering T. coriacea, T. nigripalpis and T. granulifera the pronota are parallel-sided as far as the apical constriction. In $T$. granulifera the upper surface of pronotum bears a transverse sculpture, while in T. coriacea and T. nigripalpis this is not seen. Tricondyla coriacea has a labrum and legs that are black in colour while in T. nigripalpis the labrum and part of the legs are red (Fowler, 1912).

Insects belonging to the genus Derocrania closely resemble the species of Tricondyla but differ by having smaller and more slender bodies; head less excavate between the eyes; strongly strangulate vertex; slender elongate pronotum; elongate elytra that are widened behind; long and slender antennae and legs; and apex of the last abdominal sternite being pointed in the female (Figure 6) (Fowler, 1912).

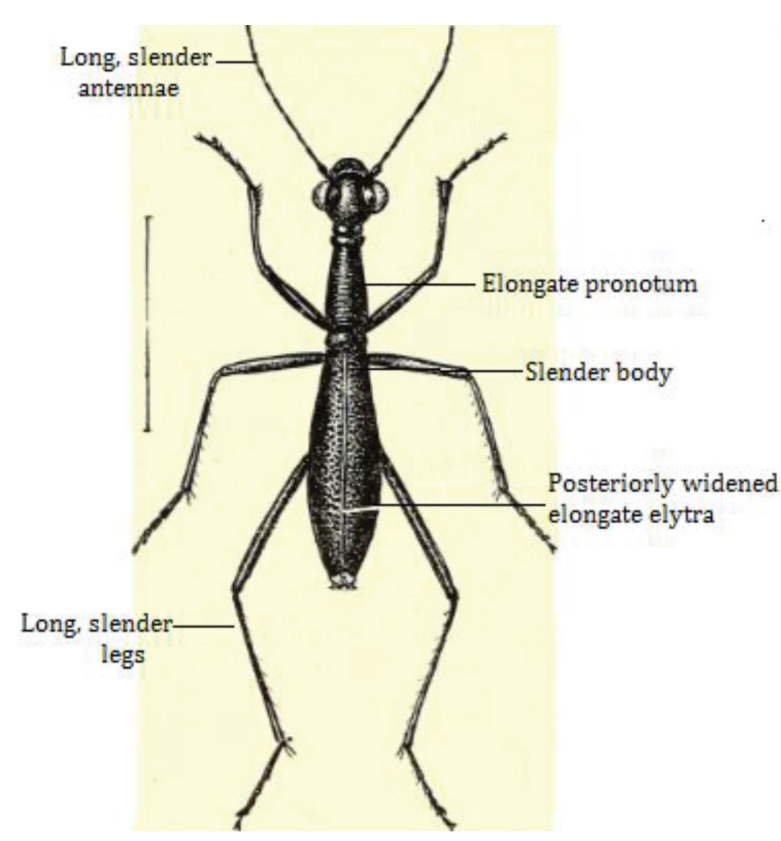

Figure 6: Habitus of Derocrania concinna (adapted from Fowler, 1912)
The ten species of Derocrania found in Sri Lanka have punctured elytra that are transversely rugose. However, Derocrania nietneri Motschulsky, D. agnes Horn, D. fusiformis Horn, D. gibbiceps Chaudoir and D. flavicornis Horn have foreheads that are not excavate and pronotum forming a distinct collum. Derocrania nietneri and $D$. agnes are slender and delicate than D. fusiformis, D. gibbiceps and D. flavicornis, and punctuation of elytra are very fine and evanescent/ fading behind (Fowler, 1912). The two species can be distinguished by the collum of the pronotum, which is shorter in D. nietneri than in D. agnes. Derocrania fusiformis, D. gibbiceps and D. flavicornis have elytra with deep and dense punctuation. Derocrania concinna Chaudoir and D. schaumi Horn have a forehead that is shallowly and widely excavate, and pronotum without a distinct collum. Elytra are more parallel and less gibbose/ curved and bulging outward behind with distantly spaced elytral punctuation in $D$. concinna, while the elytra are more widened and more gibbose behind with close elytral punctuation in D. schaumi. Derocrania nematodes Schaum has an evidently excavate forehead, pronotum without a distinct collum and elytra with transversely rugose sculpture. Derocrania scitiscabra Walker and $D$. halyi Horn have deeply excavate foreheads and pronota with distinct collums. However, D. scitiscabra is smaller in size than $D$. halyi and has strongly punctured elytra (Fowler, 1912).

\section{Life cycle of arboreal tiger beetles}

Like most Holometabola, arboreal tiger beetles pass through several stages in their life cycle before reaching adulthood (Roza \& Mermudes, 2017). Oviposition is initialised by the female who uses the sclerotised gonopophyses and ovipositor to excavate a hole in the substrate into which eggs are laid (Pearson, 1988). The larva that ecloses from the egg develops for $1-2$ years and sometimes for several years depending on the species and conditions of the environment (Roza \& Mermudes, 2017). The larvae of arboreal tiger beetles burrow vertical tunnels into bulges of tender, corky bark of trees and form tunnels with a length of about $5-7 \mathrm{~cm}$ with tunnel mouths directed upwards. These larvae wait at the tunnel opening and catch prey only at night due to the availability of prey. High numbers of ants, houseflies and other arthropods are available at night running along the trunks of trees (Trautner \& Schawaller, 1996). The larvae of arboreal tiger beetles are known to be different from the larvae of terrestrial tiger beetles in having shorter mandibles and pronotal setation; rounded pronotal anterior corners; deeply furrowed pronotal structure; short and broad femur and tibia; short tarsus 
with short spines and short and joined claws (Trautner \& Schwaller, 1996). The long larval stage of arboreal tiger beetles is followed by a short pupal stage, which is the last immature stage of the life cycle. Pupae are cylindrical in shape with sub-dorsal spines on abdominal segments $1-5$ reduced to low tubercles with short apical setae. The prothorax shows a pair of tubercles that the terrestrial tiger beetles lack. This condition in arboreal tiger beetle pupae is considered as a specialisation related to the habitat (wood) where the pupal gallery is constructed (Roza \& Mermudes, 2017).

\section{Methods for collecting arboreal tiger beetles}

\section{Sweep nets}

Sweep nets are used to collect arboreal tiger beetles in grass and brush when vegetation is not humid or thorny (Grootaert et al., 2010). Species of Tricondyla and Neocollyris have been collected from forest paths and understory vegetation in Brunei using sweep nets (Damken et al., 2017).

\section{Pitfall traps}

Pitfall traps have been mostly used to collect grounddwelling tiger beetles (Brust et al., 2005; Taboada et al., 2012) and is not considered as an efficient method to collect non-terrestrial tiger beetles (Franzen, 2004). However, species of Tricondyla have been collected using pitfall traps in Hong Kong (Aston, 2016), and $N$. labiomaculata Horn occurring in lowland mixed dipterocarp forests of Brunei have been collected using dung-baited pitfall traps (Damken et al., 2017).

\section{Hand picking/collection}

Hand picking has been used to collect arboreal tiger beetles as they are medium to large in size and do not pose a threat to health. However, the method is more effective for collecting non-flying arboreal tiger beetles. Species of Tricondyla have been collected from paths, edges and floors of dipterocarp forests of Brunei (Damken et al., 2017).

\section{Light traps}

Although light traps have been used more effectively to collect nocturnal tiger beetles such as Odontocheila Castelnau, Pentacomia Bates and Brasiella Rivalier (Wiesner \& Bandinelli, 2014), T. punctipennis Chevrolat and $T$. cyanipes Eschscholtz of the Philippines have also been collected using light traps (Cassola, 2000b).
Light traps have also been successfully used to collect arboreal tiger beetles with flight such as Neocollyris (Heterocollyris) similior Horn in the Philippines (Figure 7) (Cassola, 2000b).

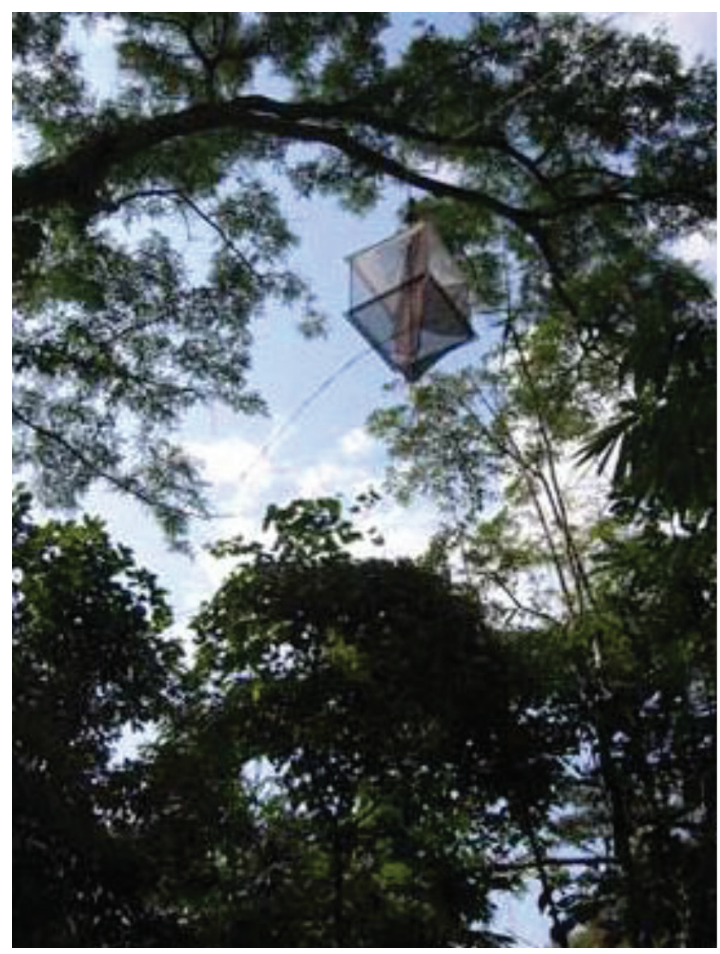

Figure 7: A canopy light trap (source: https://whitinglab.byu . edu/CanopyCollecting)

\section{Sticky traps}

This method has been effective for collecting tree trunk dwelling arboreal tiger beetle species of genera Pogonostoma, Tricondyla and Distipsidera Westwood (Pearson \& Vogler, 2001).

\section{Threats to the survival of arboreal tiger beetles}

The landmass of Sri Lanka has been cleared of forest, terraced and water systems channeled and impounded. Due to these activities the carabid fauna of the island is predominantly hydrophilous - occupying waterside dwelling, highly vagile and generalist species (Erwin, 1984). However, certain carabid species such as the arboreal tiger beetles are arboricolous (Erwin, 1984) and are highly habitat specific, associated with vegetative cover, composition of flora, understory growth, herbs and grasses (Bhargav et al., 2009). These habitat specific 
species are affected more by changes in the habitat than ubiquitous species and eurytopic species, and are known to decline with habitat destruction and pollution (pesticides and fertilisers resulting from agricultural practices, pollutants generated from road construction, mining and siltation) (Wilcove et al., 1998). In the Philippines, several tiger beetle species of Tricondyla and Neocollyris associated with forest ecosystems are considered to have disappeared due to deforestation, illegal logging and mining (Cabras et al., 2016), while species of the genus Neocollyris inhabiting branches and trunks of shrubs and trees in lowland mixed agricultural ecosystems have become vulnerable to extinction due to various anthropogenic pressures (Cabras \& Wiesner, 2016). In Hong Kong increased urbanisation and expansion of villages causing a significant loss of agricultural land, which has almost completely ceased rice cultivation, is known to have caused the demise of tiger beetles associated with this plant (Aston, 2016).

In Sri Lanka, a rapid decline in the land area under natural forest cover is evident and the wet lowland rainforests are experiencing extreme fragmentation (Dela, 2009). The wet lowland rainforests harbour nearly all the country's woody endemic flora, about $75 \%$ of the endemic fauna and all the endemic genera (Dela, 2009). Of the thirty-six tribes of Carabidae represented in the country, the arboreal forms are associated with these forests (Erwin, 1984), and apterous forms such as the arboreal tiger beetles of genera Tricondyla and Derocrania are limited to a few lowland and highland habitats of these forests.

In addition to forest degradation, introduced and invasive species impact arboreal carabid communities. The introduced guava to forests in Madagascar has threatened indigenous vegetation, and in guava dominated sites, carabid beetle communities were species poorer than elsewhere in the forest (Rainio, 2009). A recent study conducted in Sri Lanka has revealed that changes in beetle assemblages occur when habitats were invaded by the invasive plant species, Annona glabra Linnaeus (Liyanagamage et al., 2017). Conversion of habitats from complex to simplified forms (primary forests with higher number of plant species, high plant density and more canopy cover converted to secondary forests with a lower number of plant species, less plant density and canopy cover) is also known to affect arboreal fauna and a study in Papua New Guinea revealed that primary forests contained more arboreal ant species than secondary forests due to more complex vegetation structure and tree abundance (Klimes et al., 2012). Certain arboreal lizards such as the Tree Agama depend on trees for refuge and use them as foraging vantage points and are thus negatively affected by their removal (Whiting et al., 2009). Forest habitats are also considered as important in providing arboreal escape paths for arboreal fauna avoiding predators (Mattingly $\&$ Jayne, 2005). The arboreal tiger beetles of the country with $80 \%$ endemicity are very likely to occupy the wet lowland rainforests of the island. Thus, forest destruction, pollution, habitat conversion and introduced and invasive species may have serious negative implications for their survival. However, arboreal tiger beetles are known to affect the growth of various plants in undergrowth forests in tropical and subtropical Asia due to destruction of plant soft tissue for oviposition and larval tunneling (Toki et al., 2017).

\section{CONCLUSION}

According to previous literature thirty-one species of arboreal tiger beetles of which twenty-five are endemic are known to occur in Sri Lanka. Five genera-Collyris, Neocollyris, Protocollyris Tricondyla and Derocrania, are found on the island which are also known from India, and some genera from other countries of Asia. The species of Sri Lanka occur in all zones and provinces of the country and in sixteen districts. They are known to prefer forest habitats with less dense vegetation and occupy leaves, shrubs and trunks of trees. Arboreal tiger beetles are holometabolous insects having a long sedentary larval stage and short active adult stage both of which are predatory. Species can be collected via sweep nets, pitfall traps, light traps, sticky traps and hand collection. The survival of arboreal tiger beetles are severely threatened by forest destruction, pollution, habitat conversion and introduced and invasive species.

\section{Acknowledgement}

The author wishes to acknowledge the National Science Foundation of Sri Lanka (Grants: RG/2003/ZOO/01, $\mathrm{RG} / 2012 / \mathrm{NRB} / 02, \mathrm{RG} / 2017 / \mathrm{EB} / 01)$ and the University of Colombo (Grants: AP/3/2/2010/S/7, AP/3/2/2014/ $\mathrm{RG} / 06$ ).

\section{REFERENCES}

Acciavatti R.E. \& Pearson D.L. (1989). The tiger beetle genus Cicindela (Coleoptera, Insecta) from the Indian subcontinent. Annals of Carnegie Museum 58(4): 77 - 355.

Andriamampianina L., Kremen C., Vane-Wright D., Lees D. \& Razafimahatratra V. (2000). Taxic richness patterns and conservation evaluation of Madagascan tiger beetles (Coleoptera: Cicindelidae). Journal of Insect Conservation 4: 109 - 128 . 
DOI: https://doi.org/10.1023/A:1009667712512

Aston P. (2016). Catalogue and bibliography of the Hong Kong Carabidae Latreille, 1802 (Coleoptera: Adephaga), with notes on the historic boundaries of Hong Kong as related to zoological collections. Zootaxa 4121(3): 201 - 257. DOI: https://doi.org/10.11646/zootaxa.4121.3.1

Ball G.E., Acorn J.H. \& Shpeley D. (2011). Mandibles and labrum-epipharynx of tiger beetles: basic structure and evolution (Coleoptera, Carabidae, Cicindelitae). ZooKeys 147: $39-83$.

DOI: https://doi.org/10.3897/zookeys.147.2052

Bhargav V., Uniyal V.P. \& Sivakumar K. (2009). Distinctive patterns in habitat association and distribution of tiger beetles in the Shivalik landscape of North Western India. Journal of Insect Conservation 13: 459 - 473. DOI: https://doi.org/10.1007/s10841-008-9193-y

Brust M.L., Hoback W.W. \& Knisley C.B. (2005). Biology, habitat preference, and larval description of Cicindela cursitans Leconte (Coleoptera: Carabidae: Cicindelinae). The Coleopterists Bulletin 59(3): 379 - 390.

DOI: https://doi.org/10.1649/798.1

Cabras A.A., Medina M.N.D. \& Wiesner J. (2016). Tiger beetles (Coleoptera: Carabidae: Cicindelinae) of Compostella Valley province, Mindanao Island, Philippines. Biotropia 23(2): $137-143$.

DOI: https://doi.org/10.11598/btb.2016.23.2.564

Cabras A.A. \& Wiesner J. (2016). Tiger beetles (Coleoptera: Carabidae: Cicindelinae) of Mainit Hotspring and Mati protected landscape, Mindanao with notes on their ecology and threats. International Research Journal of Biological Sciences 5(9): $16-21$.

Cassola F. (2000a). Studies on tiger beetles. CXII. A new Ctenostoma from Equador (Coleoptera: Cicindelidae). Atti della Società Toscana de Scienze Naturali Memorie B(107): $61-62$.

Cassola F. (2000b). Studies on tiger beetles. CII. The Cicindelidae collected by Roland A. Müller in the Philippine Islands, with description of three new species (Coleoptera: Cicindelidae). Zoologische Mededelingen 73: $491-509$.

Cassola F. (2011). Studies of tiger beetles. CCII. Indian tiger beetle conservation (Coleoptera: Cicindelidae). ENVIS Bulletin:Wildlife and Protected Areas 14(1): 98 - 107.

Damken C., Wiesner J. \& Wahab R.A. (2017). Notes on the tiger beetles (Coleoptera: Carabidae: Cicindelinae) of Brunei Darussalam. 137. Contribution towards the knowledge of Cicindelinae. Insecta Mundi 0552: 1 - 15.

Dangalle C.D. (2012). Tiger beetles as appropriate bioindicators of environmental change and pollution. In: Environmental toxicants and their effects on species and ecosystems (eds. C.D. Dangalle, M.R. Wijesinghe \& I.C. Perera), $32^{\text {nd }}$ Annual Sessions of the Institute of Biology, Sri Lanka, pp. $55-63$.

Dangalle C.D. (2013). The current status of the tiger beetle species of the coastal habitats of Sri Lanka. Journal of Tropical Forestry and Environment 3(2): 39 - 52.

Dangalle C.D. \& Pallewatta N. (2015). An invertebrate perspective to Hutchinson's ratio using co-occurring tiger beetle (Coleoptera: Cicindelidae) assemblages. Taprobanica 7(4): $224-234$.

Dangalle C., Pallewatta N. \& Vogler A. (2011a). The current occurrence, habitat and historical change in the distribution range of an endemic tiger beetle species Cicindela (Ifasina) willeyi Horn (Coleoptera: Cicindelidae) of Sri Lanka. Journal of Threatened Taxa 3(2): 1493 - 1505. DOI: https://doi.org/10.11609/JoTT.o2501.1493-505

Dangalle C., Pallewatta N. \& Vogler A. (2011b). The occurrence of the endemic tiger beetle Cicindela (Ifasina) waterhousei in Bopath Ella, Ratnapura. Journal of the National Science Foundation of Sri Lanka 39(2): 173 - 178.

DOI: https://doi.org/10.4038/jnsfsr.v39i2.3177

Dangalle C., Pallewatta N. \& Vogler A. (2012a). Tiger beetles (Coleoptera: Cicindelidae) of ancient reservoir ecosystems of Sri Lanka. Journal of Threatened Taxa 4(4): 2490 2498.

DOI: https://doi.org/10.11609/JoTT.o2896.2490-8

Dangalle C.D., Pallewatta N. \& Vogler A.P. (2012b). Habitat specificity of tiger beetle species (Coleoptera, Cicindelidae) of Sri Lanka. Cicindela 44(1): $1-32$.

Dangalle C.D., Pallewatta N. \& Vogler A.P. (2013a). The association between body-size and habitat-type in tiger beetles (Coleoptera, Cicindelidae) of Sri Lanka. Ceylon Journal of Science (Biological Sciences) 42(1): 41 - 53. DOI: https://doi.org/10.4038/cjsbs.v42i1.5898

Dangalle C.D., Pallewatta N. \& Vogler A.P. (2014a). Distribution and habitat preferences of tiger beetles (Coleoptera: Cicindelidae) of the riverine ecosystems of Sri Lanka. Journal of Threatened Taxa 6(9): 6195 - 6203. DOI: https://doi.org/10.11609/JoTT.o3674.6195-203

Dangalle C.D., Pallewatta N. \& Vogler A.P. (2014b). Inferring population history of tiger beetle species of Sri Lanka using mitochondrial DNA sequences. Ceylon Journal of Science (Biological Sciences) 43(2): $47-63$.

DOI: http://dx.doi.org/10.4038/cjsbs.v43i2.7324

Dela J. (2009). Fourth Country Report from Sri Lanka to the United Nations Convention on Biological Diversity. Biodiversity Secretariat, Ministry of Environment and Natural Resources, Battaramulla.

Edirisinghe H.M., Dangalle C.D. \& Pulasinghe K. (2014). Predicting the relationship between body size and habitat type of tiger beetles (Coleoptera, Cicindelidae) using artificial neural networks. Journal on New Biological Reports 3(2): 97 - 110.

Erwin T.L. (1984). Composition and origin of the ground beetle fauna (Coleoptera, Carabidae). Ecology and Biogeography in Sri Lanka (eds. C.H. Fernando). Dr. W. Junk Publishers, The Hague, The Netherlands. DOI: https://doi.org/10.1007/978-94-009-6545-4_18

Erwin T.L. \& House G.N. (1978). A catalogue of the primary types of Carabidae (incl. Cicindelinae) in the collections of the United States National Museum of Natural History (USNM) (Coleoptera). The Coleopterists Bulletin 32(3): $231-255$.

Fowler W.W. (1912). Fauna of British India including Ceylon and Burma (Coleoptera General Introduction and Cicindelidae and Paussidae). Today and Tomorrow's 
Printers and Publishers, New Delhi, India.

Franzen M. (2004). Tiger beetle assemblages in a climatically transitional area of northwestern Costa Rica. Mitteilungen der Munchner Entomologischen Gesellschaft 94: 87 - 95.

Grootaert P., Pollet M., Dekoninck W. \& van Achterberg C. (2010). Sampling insects: general techniques, strategies and remarks. Manual on Field Recording Techniques and Protocols for All Taxa Biodiversity Inventories and Monitoring. Abc Taxa, Belgium.

Horn W. (1904). The Cicindelidae of Ceylon. Spolia Zeylanica 2(5): $30-45$.

Horn W. (1931). How to collect cicindelids and their larvae in Hong Kong and vicinity. The Hong Kong Naturalist 2(4): $258-261$.

Klimes P., Idigel C., Rimandai M., Fayle T.M., Janda M., Weiblen G.D. \& Novotny V. (2012). Why are there more arboreal ant species in primary than in secondary tropical forests? Journal of Animal Ecology 81: 1103 - 1112. DOI: https://doi.org/10.1111/j.1365-2656.2012.02002.x

Liyanagamage M., Pallewatta N., Dangalle C. \& Wijesundara S. (2017). Insect assemblages of Annona glabra L.; an invasive plant species in selected habitats of the wet zone. In: Conserving biodiversity through understanding relationships. Proceedings of the $37^{\text {th }}$ Annual Sessions of the Institute of Biology, Sri Lanka, 29 September, pp. 48.

Mattingly W.B. \& Jayne B.C. (2005). The choice of arboreal escape paths and its consequences for the locomotor behavior of four species of Anolis lizards. Animal Behaviour 70: $1239-1250$.

DOI: https://doi.org/10.1016/j.anbehav.2005.02.013

Naviaux R. (1984). Coleoptera, Cicindelidae. Les Cicindelés de Sri Lanka. Revue Scientifique Du Bourbonnais 57 - 80 .

Naviaux R. (1986). Coleoptera, Cicindelidae. Premier complement aux Cicindéles de Sri Lanka. Revue Scientifique Du Bourbonnais 58 - 69.

Naviaux R. (1995). Neocollyris vedda noevelle espece du Sri Lanka (Coleoptera, Cicindelidae). Bulletin de la Societe Entomologique de France 100(2): 173 - 174.

Naviaux R.L. (1991). Les Cicindéles de Thaïlande, étude faunistique (Coleoptera Cicindelidae). Bulletin Mensuel de la Société Linnéenne de Lyon 60(7): 209 - 288. DOI: https://doi.org/10.3406/linly.1991.10944

Naviaux R. (2002). Les Tricondylina(Coleoptera, Cicindelidae), Révision des genres Tricondyla Latreille et Derocrania Chaudoir et descriptions de nouveaux taxons. Mémories de la Société Entomologique de France 5: 1 - 106.

Pearson D.L. (1988). Biology of tiger beetles. Annual Review of Entomology 33: 123 - 147.

DOI: https://doi.org/10.1146/annurev.en.33.010188.001011

Pearson D.L. \& Vogler A.P. (2001). Tiger Beetles: The Diversity, Ecology and Evolution of the Cicindelidae. Cornell University Press, Ithaca, New York.

Rainio J. (2009). Carabid beetles (Coleoptera, Carabidae) as indicators of environmental change in Ranomafana National Park, Madagascar. Academic dissertation, Department of Biological and Environmental Sciences, Faculty of Biosciences, University of Helsinki, Finland.

Roza A.S. \& Mermudes J.R.M. (2017). Tiger beetles'
(Coleoptera: Carabidae, Cicindelinae) pupal stage: current state of knowledge and future perspectives. Zootaxa 4226(3): 348 - 358 .

DOI: https://doi.org/10.11646/zootaxa.4226.3.2

Saha S.K. \& Halder S.K. (1986). Tiger beetles (Coleoptera, Cicindelidae) of Silent Valley (Kerala, India). Records of the Zoological Survey of India 84(1 - 4): 137 - 142.

Saha S.K., Halder S.K. \& Biswas S. (1995). Insecta: Coleoptera: Adephaga: Fam. Rhysodidae, Paussidae and Cicindelidae. Zoological Survey of India, Fauna of West Bengal 3(6A): $1-51$.

Santos B.S. (2011). Distribution patterns of tiger beetle species in the Philippines and Southeast Asia. Journal of Entomology and Zoology Studies 2(4): 271 - 275.

Taboada A., Perez-Aguirre C. \& Assmann T. (2012). A new method for collecting agile tiger beetles by live pitfall trapping. Entomologia Experimentalis et Applicata 145: $82-87$.

DOI: https://doi.org/10.1111/j.1570-7458.2012.01316.x

Tanner V.M. (1951). Notes on some Cicindelidae of the western United States and the South Pacific Islands with a description of a new species. Great Basin Naturalist 11(1): $47-51$.

Tennent J.E. (1860). Ceylon: An Account of the Island, Physical, Historical and Topographical with Notices of its Natural History, Antiquities and Productions. Longman and Roberts, London, UK.

Thotagamuwa A., Dangalle C.D., Pallewatta N. \& Lokupitiya E. (2016). Selection of tiger beetle species as potential bioindicator organisms for coastal ecosystems of Sri Lanka. Proceedings of the Annual Research Symposium 2016, University of Colombo, Sri Lanka, pp. 295.

Toki W., Pham H.T. \& Hori M. (2017). Pupa of an arboreal tiger beetle, Neocollyris similis (Lense) (Coleoptera: Carabidae: Cicindelinae), from the internode cavity of a reed. The Coleopterists Bulletin 71(1): 202 - 203. DOI: https://doi.org/10.1649/0010-065X-71.1.202

Trautner J. \& Schawaller W. (1996). Larval morphology, biology and faunistics of Cicindelidae (Coleoptera) from Leyte, Philippines. Tropical Zoology 9: 47 - 59. DOI: https://doi.org/10.1080/03946975.1996.10539302

Wiesner J. \& Bandinelli A. (2014). Notes on the tiger beetles (Coleoptera: Cicindelidae) of Argentina. 117. Contribution towards the knowledge of Cicindelidae. Insecta Mundi 0377: 1 - 66 .

Wilcove D.S., Rothstein D., Dubow J., Phillips A. \& Losos E. (1998). Quantifying threats to imperiled species in the United States. BioScience 48(8): 607 - 615.

DOI: https://doi.org/10.2307/1313420

Whiting M.J., Chetty K., Twine W. \& Carazo P. (2009). Impact of human disturbance and beliefs on the tree agama Acanthocercus atricollis atricollis in a South African communal settlement. Oryx 43(4): 586 - 590.

DOI: https://doi.org/10.1017/S0030605309990160

Wu X.-Q. \& Shook G. (2007). Range extensions, new records, an artificial key and a list of tiger beetles of Yunnan Province, China (Coleoptera: Cicindelidae). Journal of the Entomological Research Society 9(2): 31 - 40. 